\title{
Polymyxin B/Pulmonary Surfactant Mixtures Have Increased Resistance to Inactivation by Meconium and Reduce Growth of Gram-Negative Bacteria In Vitro
}

\author{
GUIDO STICHTENOTH, PHILIPP JUNG, GABI WALTER, JAN JOHANSSON, BENGT ROBERTSON, TORE CURSTEDT, \\ AND EGBERT HERTING
}

\begin{abstract}
Department of Clinical Chemistry [G.S., B.R., T.C], Laboratory for Surfactant Research, Karolinska Hospital, S-17176 Stockholm, Sweden; Department of Pediatrics [P.J., G.W., E.H.], University Hospital of Schleswig-Holstein, Campus Lübeck, D-23538 Lübeck, Germany; Department of Molecular Biosciences [J.J.], Swedish University of Agricultural Sciences, BMC, S-75123 Uppsala, Sweden
\end{abstract}

\begin{abstract}
Pulmonary surfactant is inactivated in meconium aspiration syndrome and neonatal pneumonia. Development of an exogenous surfactant less sensitive to inactivation might be useful for treating these diseases. We investigated in vitro whether addition of the cationic cyclic membrane cross-linking peptide polymyxin $\mathrm{B}$ $(\mathrm{PxB})$ and/or calcium chloride $\left(\mathrm{CaCl}_{2}\right)$ to modified porcine surfactant Curosurf increases resistance to meconium-induced inactivation of surface activity while antimicrobial activity of PxB is maintained. To study bacterial proliferation, Escherichia coli, group B streptococci (GBS), or Staphylococcus aureus were incubated $0-5 \mathrm{~h}$ in saline or in meconium in the presence or absence of Curosurf with or without PxB. PxB and $\mathrm{CaCl}_{2}$ improved spreading and adsorption of Curosurf. Curosurf plus $\mathrm{CaCl}_{2} / \mathrm{PxB}$ needed a 4 -fold increase of meconium concentration to increase dynamic surface tension significantly compared with Curosurf plus $\mathrm{CaCl}_{2}$ alone, indicating that $\mathrm{PxB}$ further increases the resistance of Curosurf to meconium-induced inactivation. Meconium alone like meconium/Curosurf promoted growth of E. coli and GBS, but addition of Curosurf/PxB or PxB alone significantly reduced the growth of $E$. coli. Biophysical and antibacterial properties of Curosurf and $\mathrm{PxB}$ may be combined into a useful adjunct in the treatment of neonatal Gram-negative pneumonia and/or meconium aspiration syndrome. (Pediatr Res 59: 407-411, 2006)
\end{abstract}

$\mathbf{M}^{\prime}$ AS and pneumonia remain relevant causes of respiratory failure in neonates. In MAS, direct inhibition, inflammation, and, in some cases, secondary bacterial pneumonia contribute to surfactant dysfunction. This may result in hypoxia and acidosis, which further reduces surfactant activity. Meconium-induced surfactant inactivation in vitro was first described by Moses et al. (1). Minimum surface tension of bovine surfactant, measured in a PBS, increased when diluted human meconium was added. In a newborn rabbit model of meconium aspiration, surfactant treatment improved lung function and morphology (2). Pilot studies using intratracheal doses of $50-200 \mathrm{mg} / \mathrm{kg}$ of exogenous pulmonary

Received May 16, 2005; accepted October 31, 2005.

Correspondence: Guido Stichtenoth, M.D., Department of Clinical Chemistry, Laboratory for Surfactant Research, L7:03, Karolinska University Hospital, Solna, S-17176 Stockholm, Sweden; e-mail: stichtenoth@paedia.ukl-mu.luebeck.de

Supported by the Swedish Research Council (Project No. 3351), King Oscar II's Jubilee Foundation, and the German Research Council (DFG He 2072/2-2).

DOI: 10.1203/01.pdr.0000200806.32822.e6 surfactant as well as a controlled, randomized clinical study showed improved oxygenation of neonates with MAS receiving repeated high doses of surfactant (3). However, modified natural surfactants containing hydrophobic surfactant proteins B (SP-B) and C (SP-C) were more sensitive to inactivation by meconium than synthetic surfactant preparations based on artificial peptides such as SP-C analogues or the simplified peptide $\mathrm{KL}_{4}$ (4). Thus, development of surfactants that are resistant to inactivation might be useful (5).

Gram-positive bacteria like group B streptococci (GBS) or Staphylococcus aureus and Gram-negative microorganisms such as Escherichia coli, Klebsiella pneumoniae, or Enterobacter cloacae are common pathogens causing serious neonatal infections, including neonatal pneumonia $(6-8)$. The infection leads to pulmonary inflammation with accumulation of cytokines in the lung, leakage of plasma proteins into the alveoli, and surfactant inactivation. In experimental neonatal GBS pneumonia in rabbits, treatment with modified natural surfactant [Curosurf poractant alfa); Nycomed Pharma GmbH, Unterschleissheim, Germany] ) significantly reduced bacterial growth compared with control animals not receiving surfactant (9). Clinically, treatment of neonatal pneumonia includes endotracheal surfactant administration and antibiotic therapy (10).

$\mathrm{PxB}$, a cationic polypeptide antibiotic against Gramnegative bacteria is in clinical use as a topical or, rarely, a systemic antimicrobial agent. Because of its potential neuroand nephrotoxicity, PxB is used preferentially in case of bacterial resistance or intolerance to other antibiotics. PxB binds to membrane phospholipids and LPS of Gram-negative bacterial membranes, inducing pore formation, which ultimately leads to bacteriolysis (11).

PxB like SP-B may cross-link two juxtaposed phospholipid bi-layers, and addition of SP-B or PxB to synthetic pulmonary surfactant improved surface activity (12).

Abbreviations: CFU, colony-forming units; DPPC, dipalmitoylphosphatidylcholine LPS, lipopolysaccharide; MAS, meconium aspiration syndrome; PBS, pulsating bubble surfactometer PxB, polymyxin B; SP, surfactant protein; $\gamma$, surface tension 
The aim of this study was to investigate in vitro the surface activity and the antimicrobial properties of PxB/surfactant mixtures in the presence of meconium.

\section{MATERIALS AND METHODS}

Surfactant. Curosurf ( $80 \mathrm{mg} / \mathrm{mL}$, batches $02705003,194 / 09$ and 200/05) was obtained from Nycomed Pharma $\mathrm{GmbH}$. It contains approximately $41-48 \%$ saturated phosphatidylcholine (PC), 51-58\% other phospholipids, and $1 \%$ SP-B and SP-C. PxB (8100 IU/mg) was from Sigma Chemical Co. Aldrich Chemicals, Steinheim, Germany. Curosurf and PxB were mixed at a ratio of 100:1 (wt/wt)

Meconium. Human meconium from 40 healthy term neonates was collected in sterile tubes with parental consent at the University of Göttingen. The collection was approved by the local ethics committee of the medical school of Göttingen, Germany. Aliquots of the suspensions were serially diluted, transferred to agar plates, and incubated at $37^{\circ} \mathrm{C}$ for $24 \mathrm{~h}$ to investigate bacterial contamination. Samples containing $<10^{4} \mathrm{CFU} / \mathrm{g}$ were lyophilized and pooled. After lyophilization, the dry weight of the samples was 254 $\mathrm{mg} / \mathrm{g}$ meconium.

Determination of surface activity. Lyophilized meconium and surfactant were dissolved in saline in presence or absence of $1.5 \mathrm{mM}$ calcium chloride $\left(\mathrm{CaCl}_{2}\right)$. Final concentrations of Curosurf were 2.5 and $5 \mathrm{mg} / \mathrm{mL}$ and for meconium $0.08-5 \mathrm{mg} / \mathrm{mL}$. Before measurement, the samples were incubated at $37^{\circ} \mathrm{C}$ for $30 \mathrm{~min}$ under mechanical agitation.

Surface tension was determined with a PBS (Electronetics Corp., New York, NY) using bubbles with maximal surface area of $3.8 \mathrm{~mm}^{2}$. After bubble formation, surface tension at $37^{\circ} \mathrm{C}$ was first recorded under static conditions, and measurements obtained $2 \mathrm{~s}$ and $10 \mathrm{~s}$ after creation of the bubble were used as parameters of surface adsorption. After a period of $1 \mathrm{~min}$, the bubble underwent $50 \%$ cyclic area compression at a frequency of 20/min for $5 \mathrm{~min}$. The pressure gradient across the bubble wall was recorded continuously and dynamic surface tension at minimum and maximum bubble size $\left(\gamma_{\min }, \gamma_{\max }\right)$ was calculated after 5 min of pulsation (13). For each PBS measurement, approximately $40 \mu \mathrm{L}$ of sample fluid was filled in a new sample chamber. Each sample was measured five times.

Spreading rates of the various surfactant samples were evaluated using a modified Wilhelmy balance (Biegler, Mauerbach, Austria). The trough was filled with saline heated to $37^{\circ} \mathrm{C}$. The surface area was $20 \mathrm{~cm}^{2}$ and each sample was applied as a single droplet on the hypophase $4 \mathrm{~cm}$ from the dipping sensor plate. The resulting change in surface tension was recorded during 5 min after application of the test material. Each applied sample contained the amount required to coat the surface with two monolayers of saturated phospholipids, calculated with a hypothetical area of approximately $40 \mathrm{~A}^{\circ 2}$ per saturated PC molecule (14).

Based upon a pilot study (unpublished data), we chose a meconium concentration that inactivated Curosurf $/ \mathrm{CaCl}_{2}$ but not Curosurf $/ \mathrm{PxB} / \mathrm{CaCl}_{2}$. At this concentration, we studied the effects of $\mathrm{CaCl}_{2}, \mathrm{PxB}$, or $\mathrm{CaCl}_{2}$ plus $\mathrm{PxB}$ on surface activity of Curosurf in the presence or absence of meconium. These experiments were conducted in parallel in the PBS and Wilhelmy balance to confirm the results with different biophysical assays.

Bacterial growth. Bacterial growth experiments were conducted at final concentrations of $20 \mathrm{mg} / \mathrm{mL}$ meconium and $10 \mathrm{mg} / \mathrm{mL}$ Curosurf both in saline. Aliquots containing bacterial suspensions $(1 \mathrm{~mL})$ of $E$. coli (strain ATTC 25922), GBS (strain 090 Ia Colindale, a high-density variant that lacks a polysaccharide capsule, a kind gift from Stellan Håkanson, University of Umeå, Sweden), or S. aureus (strain ATTC 25923), stored at $-80^{\circ} \mathrm{C}$, were transferred to $11.5-\mathrm{mL}$ nutrient broth (Standard I, Merck, Darmstadt, Germany: $15 \mathrm{mg} / \mathrm{mL}$ peptone, $6 \mathrm{mg} / \mathrm{mL}$ sodium chloride, $3 \mathrm{mg} / \mathrm{mL}$ yeast extract, $1 \mathrm{mg} / \mathrm{mL} \mathrm{D} \mathrm{(+)-glucose)} \mathrm{and} \mathrm{incubated} \mathrm{at} 37^{\circ} \mathrm{C}$ for $16 \mathrm{~h}$. The bacteria were then diluted 1:7 in freshly warmed broth and incubated, $E$. coli for $1 \mathrm{~h}$ and $S$. aureus or GBS for $3 \mathrm{~h}$, at $37^{\circ} \mathrm{C}$ to reach the mid-logarithmic growth phase. The bacteria were centrifuged at $1800 \times g$ for $10 \mathrm{~min}$, washed twice, and thereafter resuspended in saline. Bacterial concentrations were adjusted by measuring OD of the suspensions at $595 \mathrm{~nm}$ to transfer approximately $10^{8}$ CFU to sterile tubes containing finally $1 \mathrm{~mL}$ volume of either 1) meconium, 2) Curosurf and meconium, 3) $0.1 \mathrm{mg} / \mathrm{mL} \mathrm{PxB}$ and meconium, 4) Curosurf with $0.1 \mathrm{mg} / \mathrm{mL}$ PxB and meconium, or 5) saline. After incubation periods of $0,1,3$, and $5 \mathrm{~h}$ at $37^{\circ} \mathrm{C}$ under agitation at $180 \mathrm{rpm}, 100 \mu \mathrm{L}$ aliquots of each sample were serially diluted, transferred to Petri dishes, and mixed with warm blood agar. $\mathrm{CFU}$ were counted after incubation for $24 \mathrm{~h}$ at $37^{\circ} \mathrm{C}$. Five repeats of each experiment were done.

Statistical analysis. The results of surface activity studies and bacterial growth experiments are expressed as mean $\pm \mathrm{SD}$. Statistical analysis was done using one-way ANOVA for repeated measures. Static surface tension, $\gamma_{\min }$, and $\gamma_{\max }$ from meconium-containing samples were compared with control samples without meconium using Dunnett's post test. Bonferroni's post test was used to compare static surface tension of surfactants alone versus addition of $\mathrm{CaCl}_{2}, \mathrm{PxB}$, or $\mathrm{CaCl}_{2}$ plus $\mathrm{PxB}$ in presence or absence of meconium. In bacterial growth studies, Dunnett's post test compared bacterial numbers at 1,3 , and $5 \mathrm{~h}$ with values at $0 \mathrm{~h}$ as control. Statistical calculations were conducted with GraphPad Prism 4.02 software (San Diego, CA).

\section{RESULTS}

Surface activity. Static surface tension in the PBS showed that adsorption was significantly retarded in the most diluted surfactant samples $(2.5 \mathrm{mg} / \mathrm{mL})$ containing the larger amounts of meconium $(1 \mathrm{mg} / \mathrm{mL})$, as reflected by high values for static surface tension $10 \mathrm{~s}$ after bubble formation (Table 1). Furthermore, meconium significantly increased $\gamma_{\max }$ and, at Curosurf $2.5 \mathrm{mg} / \mathrm{mL}, \gamma_{\min }$ after $5 \mathrm{~min}$ of pulsation (Table 2). This indicates meconium induced surfactant inactivation. Presence of $\mathrm{CaCl}_{2}$ and/or $\mathrm{CaCl}_{2}$ plus PxB reduced or counter-balanced effects of meconium on surfactant (Tables 1 and 2).

In spreading studies using small amounts of surfactant equivalent to approximately two monolayers of saturated PC, we found meconium and surfactant dose induced delay of adsorption (Table 3). Addition of $\mathrm{CaCl}_{2}$ and/or $\mathrm{CaCl}_{2}$ plus PxB accelerated spreading especially when given to Curosurf $5 \mathrm{mg} / \mathrm{mL}$ as reflected by values close to those obtained with Curosurf $80 \mathrm{mg} / \mathrm{mL}$ after $10 \mathrm{~s} \mathrm{(33} \mathrm{versus} 27 \mathrm{mN} / \mathrm{m}$; Table 3). Meconium-induced delay of static surface tension after $5 \mathrm{~min}$ was improved, but was not totally counter-balanced by addition of $\mathrm{CaCl}_{2}$ and/or $\mathrm{CaCl}_{2}$ plus PxB.

By using a meconium dose response assay, we focused more closely on differences between Curosurf plus $\mathrm{CaCl}_{2}$ and Curosurf plus $\mathrm{PxB} / \mathrm{CaCl}_{2}$ (Fig. 1). Addition of meconium increased $\gamma_{\min }$ and $\gamma_{\max }$ of surfactant preparations in a dosedependent manner. If meconium concentration was $\geq 0.31$ $\mathrm{mg} / \mathrm{mL}, \gamma_{\text {min }}$ of Curosurf $/ \mathrm{CaCl}_{2}$ exceeded $10 \mathrm{mN} / \mathrm{m}$ and values for $\gamma_{\min }$ and $\gamma_{\max }$ were significantly increased, compared with the control without meconium $(p<0.01)$. This indicates surfactant inactivation.

Table 1. Static surface tension in the PBS at different time points of Curosurf alone and Curosurf $+\mathrm{CaCl}_{2}$, Curosurf $+\mathrm{PxB}$, or Curosurf $+\mathrm{CaCl}_{2} / \mathrm{PxB}$ in absence (control) or presence of meconium

\begin{tabular}{|c|c|c|c|c|c|}
\hline \multirow[b]{3}{*}{ Surfactant } & \multirow[b]{3}{*}{$\mathrm{mg} / \mathrm{mL}$} & \multicolumn{4}{|c|}{ Static surface tension $(\mathrm{mN} / \mathrm{m}) /$ time } \\
\hline & & \multicolumn{2}{|c|}{$2 \mathrm{~s}$} & \multicolumn{2}{|c|}{$10 \mathrm{~s}$} \\
\hline & & Control & Meconium & Control & Meconium \\
\hline Curosurf & 2.5 & 32 & $50 *$ & & $47 *$ \\
\hline$+\mathrm{PxB}$ & & & $56 * *$ & $25-27$ & $51 * *$ \\
\hline$+\mathrm{CaCl}_{2}$ & & $26-28$ & $56 * *$ & & $51 * *$ \\
\hline$+\mathrm{CaCl}_{2} / \mathrm{PxB}$ & & & $52 * *$ & & $44 * *$ \\
\hline Curosurf & 5 & & $50 * *$ & & $44 * *$ \\
\hline$+\mathrm{PxB}$ & ) & & $49 * *$ & $26-27$ & $44 * *$ \\
\hline$+\mathrm{CaCl}_{2}$ & & $26-27$ & $46^{* *}$ & & $40 * *$ \\
\hline$+\mathrm{CaCl}_{2} / \mathrm{PxB}$ & & & $44 * *$ & & $35^{* \dagger \dagger}$ \\
\hline
\end{tabular}

One milligram per milliliter meconium was added to surfactants at 2.5 $\mathrm{mg} / \mathrm{mL}$ and $2 \mathrm{mg} / \mathrm{mL}$ meconium was added to surfactants at $5 \mathrm{mg} / \mathrm{mL}$. Values are expressed as mean of five measurements.

$* p<0.01$ vs control; ** $p<0.001$ vs control; $\dagger p<0.01$ vs $+\mathrm{PxB}$; $\ddagger p<0.01$ vs Curosurf. 
Table 2. Dynamic surface tension studies after 5 min of pulsation in the PBS of Curosurf alone, and Curosurf $+\mathrm{CaCl}_{2}$, Curosurf + $\mathrm{PxB}$, or Curosurf $+\mathrm{CaCl}_{2} / \mathrm{PxB}$ in absence (control) or presence of meconium

\begin{tabular}{|c|c|c|c|c|c|}
\hline \multirow[b]{3}{*}{ Surfactant } & \multirow[b]{3}{*}{$\mathrm{mg} / \mathrm{mL}$} & \multicolumn{4}{|c|}{ Dynamic surface tension after $5 \mathrm{~min}[\mathrm{mN} / \mathrm{m}]$} \\
\hline & & \multicolumn{2}{|c|}{$\gamma_{\min }$} & \multicolumn{2}{|c|}{$\gamma_{\max }$} \\
\hline & & Control & Meconium & Control & Meconium \\
\hline Curosurf & 2.5 & & $23^{*}$ & & $49^{*}$ \\
\hline$+\mathrm{PxB}$ & & & $17 *$ & & $48 *$ \\
\hline$+\mathrm{CaCl}_{2}$ & & $<3$ & $17 *$ & $27-32$ & $48^{*}$ \\
\hline$+\mathrm{CaCl}_{2} / \mathrm{PxB}$ & & & $6 \dagger+\S$ & & $37 \ddagger \S$ \\
\hline Curosurf & 5 & & & & $39^{*}$ \\
\hline$+\mathrm{PxB}$ & & & & & $38^{*}$ \\
\hline$+\mathrm{CaCl}_{2}$ & & $<3$ & $<3$ & $29-31$ & $33 \ddagger \S$ \\
\hline$+\mathrm{CaCl}_{2} / \mathrm{PxB}$ & & & & & 35 \\
\hline
\end{tabular}

One milligram per milliliter meconium was added to surfactants at 2.5 $\mathrm{mg} / \mathrm{mL}$ and $2 \mathrm{mg} / \mathrm{mL}$ meconium was added to surfactants at $5 \mathrm{mg} / \mathrm{mL}$. Values are expressed as mean of five measurements.

$* p<0.001$ vs control; $\dagger p<0.01$ vs $+\mathrm{CaCl}_{2} ; \ddagger p<0.01$ vs $+\mathrm{PxB}$; $\S p<0.01$ vs Curosurf.

Addition of $1 \% \mathrm{PxB}$ to Curosurf $/ \mathrm{CaCl}_{2}$ shifted the dose response curves to the right, i.e. a higher meconium concentration was needed for surfactant inactivation. In mixtures containing Curosurf and $\mathrm{PxB}$, a 4-fold increase of the meconium concentration was needed to increase $\gamma_{\min }$ and $\gamma_{\max }$ significantly compared with control samples with only surfactant. Thus, addition of $\mathrm{PxB}$ to Curosurf $/ \mathrm{CaCl}_{2}$ further increases resistance to meconium-induced inactivation.

Bacterial growth. Concentrations of E. coli (Fig. 2A), GBS (Fig. $2 B$ ), and $S$. aureus (data not shown) in samples containing only saline showed no significant change during $5 \mathrm{~h}$ of incubation.

In meconium-containing samples, the concentration of Gram-positive GBS increased over the incubation time, whereas we did not observe any change in growth for $S$.

Table 3. Static surface tension studies in the Wilhelmy balance at different time points of Curosurf alone, and Curosurf $+\mathrm{CaCl}_{2}$, Curosurf $+\mathrm{PxB}$, or Curosurf $+\mathrm{CaCl}_{2} / \mathrm{PxB}$ in absence (control) or presence of meconium.

\begin{tabular}{|c|c|c|c|c|c|}
\hline \multirow[b]{3}{*}{ Surfactant } & \multirow[b]{3}{*}{$\mathrm{mg} / \mathrm{mL}$} & \multicolumn{4}{|c|}{ Static surface tension $(\mathrm{mN} / \mathrm{m}) /$ time } \\
\hline & & \multicolumn{2}{|c|}{$10 \mathrm{~s}$} & \multicolumn{2}{|c|}{$5 \mathrm{~min}$} \\
\hline & & Control & Meconium & Control & Meconium \\
\hline Curosurf & 2.5 & 73 & 71 & 53 & 58 \\
\hline$+\mathrm{PxB}$ & 1 & & $72 * *$ & & $56^{* *}$ \\
\hline$+\mathrm{CaCl}_{2}$ & & $55-60 \S$ & 68 & $27-29 \S$ & $51 * *$ \\
\hline$+\mathrm{CaCl}_{2} / \mathrm{PxB}$ & & & $66^{*}$ & & $51^{* *}$ \\
\hline Curosurf & 5 & 53 & $70 * *$ & & $54 * *$ \\
\hline$+\mathrm{PxB}$ & & 49 & $68 * *$ & & $49 * *$ \\
\hline$+\mathrm{CaCl}_{2}$ & & $43 \S$ & $62 * *$ & $26-27$ & $45 * * \S$ \\
\hline$+\mathrm{CaCl}_{2} / \mathrm{PxB}$ & & $33 \dagger+\S$ & $61 * * \S$ & & $46^{* *} \S$ \\
\hline
\end{tabular}

One milligram per milliliter meconium was added to surfactants at 2.5 $\mathrm{mg} / \mathrm{mL}$ and $2 \mathrm{mg} / \mathrm{mL}$ meconium was added to surfactants at $5 \mathrm{mg} / \mathrm{mL}$. Values are expressed as mean of three measurements. Static surface tension of Curosurf at the commercially available dose of $80 \mathrm{mg} / \mathrm{mL}$ after $10 \mathrm{~s}$ and $5 \mathrm{~min}$ was $27 \mathrm{mN} / \mathrm{m}$.

$* p<0.01$ vs control; ** $p<0.001$ vs control $\dagger p<0.01 v s+\mathrm{CaCl}_{2}$; $\ddagger p<0.01 v s+\mathrm{PxB} ; \S p<0.01$ vs Curosurf.

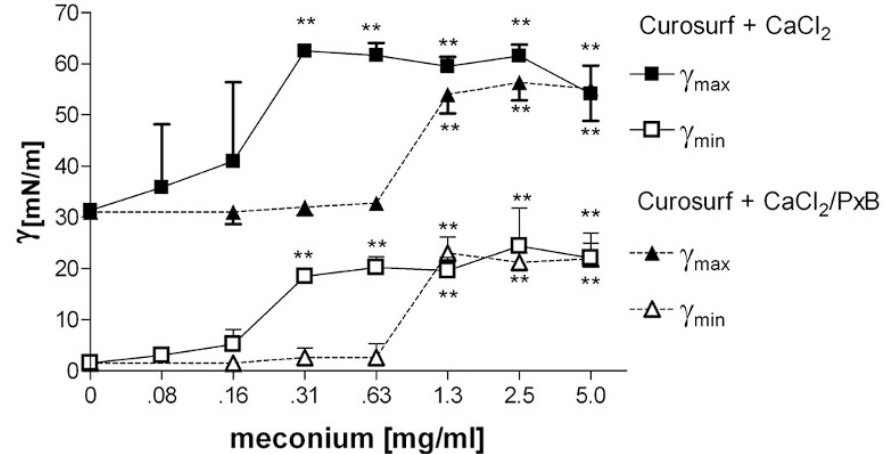

Figure 1. Effects of increasing meconium concentrations on minimum $\left(\gamma_{\min }\right)$ and maximum surface tension $\left(\gamma_{\max }\right)$ of Curosurf $2.5 \mathrm{mg} / \mathrm{mL}$ and Curosurf 2.5 $\mathrm{mg} / \mathrm{mL}$ plus $1 \%$ (wt/wt) PxB both in presence of $1.5 \mathrm{mM} \mathrm{CaCl}_{2}$. Values were recorded after 5 min of pulsation in the PBS and are expressed as mean \pm SD of $\gamma_{\min }$ and $\gamma_{\max }{ }^{* *} p<0.01$ vs $0 \mathrm{mg} / \mathrm{mL}$ meconium; $n=5$ experiments.

aureus. After $5 \mathrm{~h}$ of incubation, a significant proliferation of GBS in samples containing meconium $(p<0.05)$ and meconium/Curosurf/PxB $(p<0.01)$ compared with the controls at $0 \mathrm{~h}$ was found (Fig. 2B).

The concentration of $E$. coli significantly increased by a factor of 100 in meconium after 3 and $5 \mathrm{~h}(p<0.05)$ and in meconium/Curosurf mixtures after $5 \mathrm{~h}$ of incubation $(p<$ 0.01). In contrast, addition of PxB or Curosurf plus PxB to meconium led to a significant decrease of the proliferation of E. coli already after $1 \mathrm{~h}(p<0.01)$. After $5 \mathrm{~h}$, the bacterial count was reduced at least by a factor of $10^{4}$ (Fig. $2 \mathrm{~B}$ ). The growth of E. coli in Curosurf plus PxB was slightly but not significantly higher than in PxB only.

\section{DISCUSSION}

In MAS, meconium-stained amniotic fluid enters the alveolar space, where meconium may interfere with surfactant function. For better understanding of the interaction between meconium and surfactant it would be useful to have an estimate of the intrapulmonary amounts of meconium and surfactant in babies with MAS. In term neonates, the surfactant pool size is $50-100 \mathrm{mg} / \mathrm{kg}$ (15) and the alveolar volume defined as the functional residual capacity is $25-30 \mathrm{~mL} / \mathrm{kg}$ (16). Assuming uniform distribution of the surfactant pool in the still fluid-filled alveolar compartment, the surfactant concentration is at least $2.5-3 \mathrm{mg} / \mathrm{mL}$, which is similar to the concentrations used in this study.
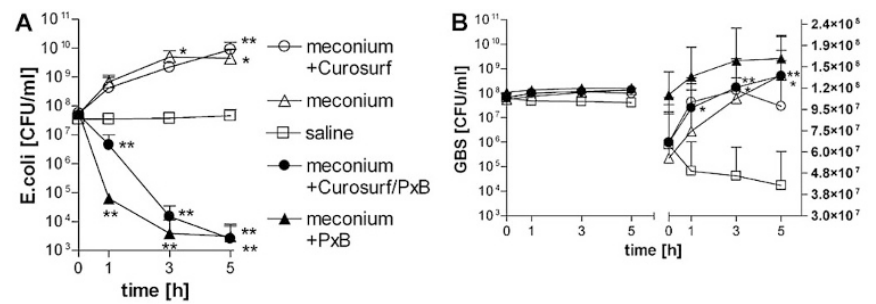

Figure 2. Growth of $(A) E$. coli and (B) GBS in saline, meconium, meconium plus Curosurf, meconium plus PxB, and meconium plus Curosurf and PxB. Values are expressed as mean $\pm \mathrm{SD}$ of five experiments. ${ }^{*} p<0.05$; $* * p<$ $0.01 v s$ time $=0 \mathrm{~h}$. To enable comparison, growth of GBS is shown on two logarithmic scales, of which the left side is identical to panel $A$. 
No information about the amount of meconium in lungs of neonates with MAS is available. In our study, we used lyophilized meconium at concentrations up to $5 \mathrm{mg} / \mathrm{mL}$ equivalent to approximately $20 \mathrm{mg} / \mathrm{mL}$ native meconium corresponding to 6-40 $\mathrm{g}$ in $0.3-2 \mathrm{~L}$ total amniotic fluid at term (17). Because the daily excretion of meconium is approximately $5 \mathrm{~g}(18)$, the concentrations used in our studies are within the expected range of MAS.

In our study, we used surfactant phospholipid concentrations of 2.5 or $5 \mathrm{mg} / \mathrm{mL}$ to investigate differences in resistance to meconium-induced inactivation. In the absence of meconium, PxB significantly reduced static surface tension only at $2.5 \mathrm{mg} / \mathrm{mL}$ Curosurf in the Wilhelmy balance, whereas no improvement was seen at $5 \mathrm{mg} / \mathrm{mL}$ or when identical samples were tested for static or dynamic surface tension in the PBS. Calkovska et al. (19) found improved dynamic surface activity after addition of $2 \%$ PxB to Curosurf $2 \mathrm{mg} / \mathrm{mL}$. We used slightly higher Curosurf concentrations and found, even without addition of PxB, $\gamma_{\min }<3 \mathrm{mN} / \mathrm{m}$. Kobayashi et al. (20) found concentrations of porcine surfactant, as used in our and the study of Calkovska, as critical to obtain optimal $\gamma_{\min }<3$ $\mathrm{mN} / \mathrm{m}$ in the PBS. After addition of $0.3 \mathrm{mg} / \mathrm{mL}$ meconium, Curosurf $/ \mathrm{CaCl}_{2}$ was inactivated, whereas $1.3 \mathrm{mg} / \mathrm{mL}$ meconium were needed to inactivate Curosurf/ $/ \mathrm{CaCl}_{2} / \mathrm{PxB}$. In a pilot study, we found similar improvement of resistance to meconium-induced inactivation after addition of $1 \%$ PxB to Curosurf $/ \mathrm{CaCl}_{2}$ (unpublished data).

Several strategies have been used to increase the resistance of exogenous surfactant to inactivation (21). Moses et al. (1) showed that an increase of the concentration resulted in increased surfactant resistance in a dose-dependent, but not stoichiometric manner. Sun et al. (22) studied the effects of increasing doses of human meconium on Curosurf at 10 $\mathrm{mg} / \mathrm{mL}$, i.e. a four times higher phospholipid concentration compared with our present investigation, and found inactivation at meconium concentrations of $2.5 \mathrm{mg} / \mathrm{mL}$ (wt/wt). These observations confirmed that modified natural surfactants at concentrations $<5 \mathrm{mg} / \mathrm{mL}$ are more sensitive to inactivation in vitro than at concentrations $\geq 10 \mathrm{mg} / \mathrm{mL}$.

Another strategy for improving the resistance of surfactant to inactivation is to add nonionic or ionic polymers. These polymers reversed meconium-induced surfactant inactivation in vitro and improved lung function of animals with meconium-induced lung injury $(23,24)$. Recently, Lu et al. (25) showed that the anionic polymer hyaluronic acid at $1-1.25$ $\mathrm{mg} / \mathrm{mL}$ in vitro prevented serum induced inactivation of different surfactants.

Furthermore, the surfactant protein content may improve the resistance to inactivation. Curosurf enriched with 5\% SP-A (normally absent in the product) had an increased resistance to inactivation by meconium, fibrinogen, albumin, and serum in vitro and improved pulmonary compliance in immature newborn rabbits after intratracheal instillation of fibrinogen compared with controls treated with only Curosurf (26). In vitro, natural rabbit surfactant (containing about 5\% SP-A) was more resistant to inactivation by human meconium than the modified natural surfactants Curosurf, Alveofact, or Survanta (4).
PxB may connect lipid vesicles thus enlarging the "surfaceassociated surfactant reservoir" (27) in the hypophase and making phospholipids readily available for surface adsorption in the pulsating bubble. Moreover, PxB promoted bidirectional transfer of monoionic phospholipids like phosphatidylglycerol, but not of zwitterionic molecules such as dipalmitoylphosphatidylcholine (DPPC) (28). Enrichment of DPPC, the main component of surfactant, at the air liquid interface of the lung is believed to be a significant function of surfactant proteins (29). We speculate that PxB might contribute to this refinement by sorting the phospholipids.

In the absence of meconium, Curosurf at concentrations 1-20 $\mathrm{mg} / \mathrm{mL}$ shows a bactericidal dose-dependent effect on GBS, but not on E. coli or $S$. aureus in absence of meconium (30). In this study, addition of meconium or meconium/ Curosurf enhanced the growth of E. coli and GBS, but not of S. aureus. Furthermore, none of the bacterial species showed growth in nutrient-free saline. In rats, intratracheal instillation of $E$. coli combined with meconium increased mortality caused by bronchopneumonia, compared with controls treated with $E$. coli and saline (31). Meconium at concentrations $\geq 3$ $\mathrm{mg} / \mathrm{mL}$ in amniotic fluid promoted growth of E. coli and Listeria monocytogenes but reduced growth of S. aureus (32). Data from a recent study suggested that meconium counteracts the bacteriostatic effects of amniotic fluid and enhances the growth of GBS more than that of E. coli. Furthermore, the proliferation of both bacteria increased with meconium concentration and incubation time (33). Meconium diluted in saline to $20 \mathrm{mg} / \mathrm{mL}$ but not saline amplified growth of $E$. coli, GBS, S. aureus, and several other Gram-positive and Gramnegative bacterial pathogens (34).

Our data demonstrate that PxB with and without Curosurf reduces the growth of $E$. coli but not of GBS or $S$. aureus in meconium suspensions. $\mathrm{PxB}$ has potent bactericidal activity against Gram-negative bacteria (11) but no significant activity against Gram-positive bacteria or fungi (35).

Local pulmonary administration of aerosolized PxB has been used in treatment of chronic Gram-negative infections, as in cystic fibrosis (11). To increase local antimicrobial effects, tobramycin has been incorporated in liposomes, which is currently under preclinical investigation (36). In rats with experimental pulmonary Pseudomonas aeruginosa infection, treatment with PxB incorporated in liposomes, composed of DPPC and cholesterol, resulted in lower bacterial counts per lung compared with treatment with free PxB or liposomes without $\mathrm{PxB}(37,38)$. The efficiency of $\mathrm{PxB}$ incorporation depended on liposome composition (38). The amounts of PxB entering surfactant lipid vesicles after addition to the surfactant suspension, as used in this study, are not known.

PxB and SP-C bind in a stoichiometric manner to the lipid A moiety of LPS, which is part of the Gram-negative outer membrane $(39,40)$. In Figure $2 A$, the curve of PxB alone shows a more rapid reduction of $E$. coli during the first hour, indicating a faster reduction of bacterial growth compared with Curosurf/PxB. However, a major binding of SP-C to LPS in Curosurf/PxB samples seems unlikely, since this difference of bacterial killing was not statistically significant. 
The recommended dose level for intratracheal administration of exogenous modified natural pulmonary surfactant is $100-200 \mathrm{mg} / \mathrm{kg}$ body weight. Calkovska et al. (19) suggested an increased resistance of Curosurf to albumin-induced inactivation in vitro after addition of PxB $2 \%$ (wt/wt), corresponding with $2-4 \mathrm{mg} / \mathrm{kg}$ body weight. For aerosolized free $\mathrm{PxB}$, a maximum dose of $2.5 \mathrm{mg} / \mathrm{kg} / \mathrm{d}$ divided in four doses is recommended for adults with normal renal clearance (35). Therefore, we used PxB at a concentration of $1 \%$, corresponding to $1-2 \mathrm{mg} \mathrm{PxB} / \mathrm{kg}$ body weight, to approach clinically usable doses.

In summary, PxB-containing pulmonary surfactant is more resistant to inactivation by human meconium than modified natural surfactant in vitro. Antimicrobial activity of $\mathrm{PxB}$ against $E$. coli is maintained when $\mathrm{PxB}$ is added to pulmonary surfactant, and it is not significantly different from PxB alone. Thus, PxB combined with exogenous surfactant may be a useful adjunct in the therapy of neonatal pneumonia and/or MAS and should be further evaluated in animal models.

\section{REFERENCES}

1. Moses D, Holm BA, Spitale P, Liu M, Enhorning G 1991 Inhibition of pulmonary surfactant by meconium. Am J Obstet Gynecol 164:477-481

2. Sun B, Curstedt T, Song GW, Robertson B 1993 Surfactant improves lung function and morphology in newborn rabbits with meconium aspiration. Biol Neonate 63:96-104

3. Findlay RD, Taeusch HW, Walther FJ 1996 Surfactant replacement therapy for meconium aspiration syndrome. Pediatrics 97:48-52

4. Herting E, Rauprich P, Stichtenoth G, Walter G, Johansson J, Robertson B 2001 Resistance of different surfactant preparations to inactivation by meconium. Pediatr Res 50:44-49

5. Johansson J, Curstedt T, Robertson B 2001 Artificial surfactants based on analogues of SP-B and SP-C. Pediatr Pathol Mol Med 20:501-518

6. Mifsud AJ, Efstratiou A, Charlett A, McCartney AC; Health Protection Agency Group B Streptococcus Working Group 2004 Early-onset neonatal group B streptococcal infection in London: 1990-1999. BJOG 111:1006-1011

7. Healy CM, Palazzi DL, Edwards MS, Campbell JR, Baker CJ 2004 Features of invasive staphylococcal disease in neonates. Pediatrics 114:953-961

8. Cordero L, Rau R, Taylor D, Ayers LW 2004 Enteric Gram-negative bacilli bloodstream infections: 17 years' experience in a neonatal intensive care unit. Am J Infect Control 32:189-195

9. Herting E, Sun B, Jarstrand C, Curstedt T, Robertson B 1997 Surfactant improves lung function and mitigates bacterial growth in immature ventilated rabbits with experimentally induced neonatal group B streptococcal pneumonia. Arch Dis Child Fetal Neonatal Ed 76:3-8

10. Herting E, Gefeller O, Land M, van Sonderen L, Harms K, Robertson B 2000 Surfactant treatment of neonates with respiratory failure and group B streptococcal infection. Members of the Collaborative European Multicenter Study Group. Pediatrics 106:957-964

11. Evans ME, Feola DJ, Rapp RP 1999 Polymyxin B sulfate and colistin: old antibiotics for emerging multiresistant Gram-negative bacteria. Ann Pharmacother 33:960-967

12. Zaltash S, Palmblad M, Curstedt T, Johansson J, Persson B 2000 Pulmonary surfactant protein B: a structural model and a functional analogue. Biochim Biophys Acta 1466:179-186

13. Enhorning G 1977 Pulsating bubble technique for evaluating pulmonary surfactant. J Appl Physiol 43:198-203
14. Notter RH, Tabak SA, Mavis RD 1980 Surface properties of binary mixtures of some pulmonary surfactant components. J Lipid Res 21:10-22

15. Rebello CM, Jobe AH, Eisele JW, Ikegami M 1996 Alveolar and tissue surfactant pool sizes in humans. Am J Respir Crit Care Med 154:625-628

16. Schmalisch G, Wauer RR 1993 [Percentile curves of functional residual capacity of newborn infants.] Monatsschr Kinderheilkd 141:714-720

17. Brace RA, Wolf EJ 1989 Normal amniotic fluid volume changes throughout pregnancy. Am J Obstet Gynecol 161:382-388

18. Aziz S, Leroy P, Servaes R, Eggermont E, Fevery J 2001 Bilirubin-IXbeta is a marker of meconium, like zinc coproporphyrin. J Pediatr Gastroenterol Nutr 32:287292

19. Calkovska A, Some M, Linderholm B, Johansson J, Curstedt T, Robertson B 2005 Biophysical and physiological properties of porcine surfactant enriched with polymyxin B. Biol Neonate 88:101-108

20. Kobayashi T, Shido A, Nitta K, Inui S, Ganzuka M, Robertson B 1990 The critical concentration of surfactant in fetal lung liquid at birth. Respir Physiol 80:181-192

21. Taeusch HW 2000 Treatment of acute (adult) respiratory distress syndrome. The holy grail of surfactant therapy. Biol Neonate 77:2-8

22. Sun B, Curstedt T, Robertson B 1993 Surfactant inhibition in experimental meconium aspiration. Acta Paediatr 82:182-189

23. Tashiro K, Cui XG, Kobayashi T, Curstedt T, Robertson B 2003 Modified protocols for surfactant therapy in experimental meconium aspiration syndrome. Biol Neonate $83: 49-56$

24. William Taeusch H, Lu KW, Goerke J, Clements JA 1999 Nonionic polymers reverse inactivation of surfactant by meconium and other substances. Am J Respir Crit Care Med 159:1391-1395

25. Lu KW, Goerke J, Clements JA, Taeusch HW 2005 Hyaluronan decreases surfactant inactivation in vitro. Pediatr Res 57:237-241

26. Sun B, Curstedt T, Lindgren G, Franzen B, Alaiya AA, Calkovska A, Robertson B 1997 Biophysical and physiological properties of a modified porcine surfactant enriched with surfactant protein A. Eur Respir J 10:1967-1974

27. Schurch S, Qanbar R, Bachofen H, Possmayer F 1995 The surface-associated surfactant reservoir in the alveolar lining. Biol Neonate 67:61-76

28. Cajal Y, Ghanta J, Easwaran K, Surolia A, Jain MK 1996 Specificity for the exchange of phospholipids through polymyxin B mediated intermembrane molecular contacts. Biochemistry 35:5684-5695

29. Veldhuizen EJ, Batenburg JJ, van Golde LM, Haagsman HP 2000 The role of surfactant proteins in DPPC enrichment of surface films. Biophys J 79:3164-3171

30. Rauprich P, Moller O, Walter G, Herting E, Robertson B 2000 Influence of modified natural or synthetic surfactant preparations on growth of bacteria causing infections in the neonatal period. Clin Diagn Lab Immunol 7:817-822

31. Bryan SC 1967 Enhancement of bacterial infection by meconium. Johns Hopkins Med J 121:9-13

32. Florman AL, Teubner D 1969 Enhancement of bacterial growth in amniotic fluid by meconium. J Pediatr 74:111-114

33. Eidelman AI, Nevet A, Rudensky B, Rabinowitz R, Hammerman C, Raveh D, Schimmel MS 2002 The effect of meconium staining of amniotic fluid on the growth of Escherichia coli and group B streptococcus. J Perinatol 22:467-471

34. Lembet A, Gaddipati S, Holzman IR, Berkowitz RL, Bottone EJ 2003 Meconium enhances the growth of perinatal bacterial pathogens. Mt Sinai J Med 70:126-129

35. Horton J, Pankey GA 1982 Polymyxin B, colistin, and sodium colistimethate. Med Clin North Am 66:135-142

36. Marier JF, Brazier JL, Lavigne J, Ducharme MP 2003 Liposomal tobramycin against pulmonary infections of Pseudomonas aeruginosa: a pharmacokinetic and efficacy study following single and multiple intratracheal administrations in rats. J Antimicrob Chemother 52:247-252

37. Omri A, Suntres ZE, Shek PN 2002 Enhanced activity of liposomal polymyxin B against Pseudomonas aeruginosa in a rat model of lung infection. Biochem Pharmacol 64:1407-1413

38. McAllister SM, Alpar HO, Brown MR 1999 Antimicrobial properties of liposomal polymyxin B. J Antimicrob Chemother 43:203-210

39. Morrison DC, Jacobs DM 1976 Binding of polymyxin B to the lipid A portion of bacterial lipopolysaccharides. Immunochemistry 13:813-818

40. Augusto L, Le Blay K, Auger G, Blanot D, Chaby R 2001 Interaction of bacterial lipopolysaccharide with mouse surfactant protein $\mathrm{C}$ inserted into lipid vesicles. Am J Physiol Lung Cell Mol Physiol 281:776-785 